\title{
Conservation Farming System of Vegetable Crops in Upstream Areas of Subwatershed Cikapundung
}

\author{
*Nana Sutrisna ${ }^{1}$ and Olivia Oktorie ${ }^{2}$ \\ ${ }^{1}$ Researcher of Assesment Institute for Agricultural Technologi (AIAT), Riau, Indonesia \\ ${ }^{2}$ Master Program of Geography Education and Pascasarjana Universitas Negeri Padang, Indonesia \\ Email: natrisna@yahoo.co.id \\ *Corresponding Author, Received: May 10, 2019, Revised: May 18, 2019, Accepted: May 23, 2019
}

\begin{abstract}
The function change of land in upstream areas of subwatershed Cikapundung is very difficult to control. Most of the land has been turned into residential areas and vegetable crops. Land is currently a source of life, so it is exploited to get maximum results and income. If it is not managed properly, the land will be degraded and eventually become critical. In order for the land to be sustainable it needs an environmentally friendly farming system for vegetable conservation The results showed that there were two technologies for specific vegetable crop conservation systems in upstream areas of subwatershed Cikapundung that were environmentally friendly, namely (1) Conservation farming system of bench terrace conservation, beds cutting slopes, using manure + lime, plastic mulch installed, planting system of intercropping/ overlapping rotating vegetables on land with slope of $15-25 \%$. The conservation farming system is able to control erosion from 69.93 to $7.18 \mathrm{t} / \mathrm{ha} / \mathrm{year}$ or by $89.73 \%$ and (2) a farming system for conservation of ridge terraces, beds cutting slopes, using manure + lime, installed plastic mulch, system for planting intercropping/overlapping vegetables on land with a slope of $8-15 \%$. The conservation farming system is able to reduce erosion from 37.41 to $15.27 \mathrm{t} / \mathrm{ha} /$ year or $59.18 \%$. The two conservative farming systems above are financially profitable as indicated by the value of BC Ratio $>1, N V P>0$, and IRR $>$ The prevailing Social Discount Rate or Bank interest, which is around $12 \%$ indicated by the value of $\mathrm{BC}$ Ratio $>1$, NVP $>0$, and IRR>Current Social Discount Rate or Bank interest, which is around $12 \%$.
\end{abstract}

Keywords: Conservation Farming System, Vegetable Crops, Upstream Areas of The Subwatershed Cikapundung

\section{Introduction}

The of population growth rate and the increasing need for life have resulted in changes in land use in upstream areas of the subwatershed Cikapundung, Lembang District, West Bandung Regency, West Java Province. The upstream areas of subwatershed Cikapundung which was originally dominated by forests and is a conservation area, has now turned into a residential area and agricultural cultivation of annual crops, namely vegetables. According to Hermon (2001); Sitorus (2007); Hermon (2011); Oktorie (2017), changes in land use of upstream watersheds will cause complex problems physically, economically and socially both in the upstream and downstream watersheds.

Problems that are often experienced due to vegetable farming activities in the upstream areas of subwatershed Cikapundung are soil erosion, runoff during the rainy season and drought during the dry season. Meanwhile, the problem that is often experienced in the downstream areas is river sedimentation, fluctuations in river flow (flooding during the rainy season and drought in the dry season). If it is not managed properly, it can accelerate land degradation and eventually become critical (Suroso and Susanto, 
2006; Hermon, 2010; Hermon, 2012; Hermon, 2015; Hermon, 2016; Hermon, 2017). On the other hand, most agricultural areas in upstream areas of subwatershed Cikapundun are already owned by farmers, making it difficult to be reallocated. In addition, the area is the main source of farmers' income, so the land is exploited to get maximum results. In order for the land to be sustainable, one of the efforts that can be done is that farmers are required to apply innovative technology for farming vegetable conservation.

The results of the study by Sutrisna et al., (2010), innovative technology for vegetable crop conservation that can be applied in the upstream Cikapundung sub-watershed is a farming system based on location-specific conservation resources. The farming system prioritizes the potential of location-specific agricultural resources and farmer participation. Farmers have the ability to make fundamental changes in land use, because farmers better understand the potentials and problems that exist around them and feel directly the benefits of conservation actions. The role of the government is to encourage farmer participation in expressing and implementing appropriate ways of solving farming problems faced. Syafrudin et al,. (2004) stated that conservation farming systems that utilize location-specific resources based on characteristics, capabilities, and suitability, will be efficient, high-yielding, and sustainable.

This paper will describe the superiority of the results of the study of the application of a system of conservation of vegetable crops in the upstream areas of the subwatershed Cikapundung. In addition, previously it will describe the characteristics and dynamics of changes in land use, and the level of land damage that has occurred in the upstream part of the Cikapundung watershed.

\section{Characteristics and Dynamics of Changes in Land Use in Upstream Areas of Subwatershed Cikapundung}

The upstream areas of subwatershed Cikapundung is located in northern Bandung, which is part of the North Bandung Region (KBU). The geographical position is located at $06^{\circ} 45^{\prime} 16^{\prime \prime}-06^{\circ} 53^{\prime} 12^{\prime \prime}$ LS and $107^{\circ} 35^{\prime} 30^{\prime \prime}-107^{\circ} 44^{\prime} 58^{\prime \prime} \mathrm{BT}$. The upstream areas of subwatershed Cikapundung has a tropical climate that is affected by the monsoon wind and has two seasons, namely the rainy season (MH) and the dry season (MK). MH ranges from November to May and the Court ranges from June to October. Lands in the Cikapundung sub-watershed developed from young and old volcanic parent materials dominated by andesite pyroxene and andesite breccia, others in the form of tufa breccia and crystalline tufa, young volcanic parent material originating from the Tangkuban Perahu mountain eruption. According to Soehardjo and Soepraptohardjo (1981) soil classification in Darsiharjo (2004), soil types in the upper Cikapundung sub-watershed consist of Brown Andosol soil, Brown Latosol, and Andosol associations with Brown Regosol. The upstream areas of subwatershed Cikapundung has a varied topography, namely flat, bumpy, hilly and mountainous with an altitude of 800-2,200 $\mathrm{m}$ above sea level (asl). The upstream slope class of the Cikapundung sub-watershed also varies, namely sloping, rather steep, steep and very steep. The percentage of the largest slope class is rather steep with a slope of $15-25 \%$ (Table 1 ).

Table 1.Slope Classand Area in Upstream Areas of Subwatershed Cikapundung

\begin{tabular}{llll}
\hline Slope & \multirow{\%}{*}{ Slope Class } & \multicolumn{2}{c}{ Spaciuos } \\
\cline { 3 - 4 } & & ha & \% \\
\hline $0-3$ & Hampir Datar & 244,184 & 3,50 \\
$3-8$ & Agak Melandai & $1.634,429$ & 23,42 \\
$8-15$ & Agak Melereng atau Sangat Melereng & 875,098 & 12,54 \\
$15-25$ & Agak Curam & $1.997,850$ & 28,63 \\
$25-45$ & Curam & $1.774,677$ & 25,43 \\
$>45$ & Sangat curam & 451,512 & 6,47 \\
\hline Total & & $6.977,910$ & 100,00 \\
\hline
\end{tabular}

Corrugated, hilly, and/or mountainous topographic conditions and their agroecosystems including dry land are very vulnerable to degradation. Therefore, upstream watersheds must be maintained according to their functions, namely conservation. The upstream area of the river was originally a protected area with dense and lush vegetation, functioning as a catchment area and source of water, food and medicine for the 
life of living things. The government has designated the area as a conservation area and protected area. However, with increasing population growth and increasing necessities of life, the forest in the area has been converted, used for settlement and used as agricultural land. The most dominant farming activities in upstream areas of subwatershed Cikapundung are vegetables, which is around $67.2 \%$. Vegetable farming systems carried out by farmers are agribusiness oriented. According to Syahyuti (2006), agribusiness is all activities related to the cultivation of plants and animals (agricultural, livestock, fisheries, and forestry commodities) that are market oriented and the acquisition of added value. Vegetable farming systems that are oriented to agribusiness, land use is intensified, because farming activities that are carried out are not only fulfilling the livelihoods of farmers but are more profit oriented. If these activities are not balanced with proper land and plant management, the chances of land damage will be even greater.

\section{Level of Land Damage in The Upstream Areas of Subwatershed Cikapundung}

According to Wicaksono (2003) land use is very influential on soil damage. Soil damage can occur due to several things and most importantly in wet tropical areas and sloping land such as in upstream areas of subwatershed Cikapundung is erosion by water (Simonato et al., 2002). Erosion can result in a loss of soil layers that are relatively rich in nutrients and organic matter and have good physical properties for the roots of the anchored plants. Damage to land or land has long been known by the general public, experts and decision makers. Until now there has been no unity of views regarding the assessment of the meaning of land/land damage that might be caused by differences in interests in the use of the land itself. Based on observations in several locations, the level of soil damage in the upper reaches of the Cikapundung subwatershed has been classified as rather heavy, with more than $75 \%$ of the top layer being lost (Sutrisna and Surdianto, 2007). Soil erosion has resulted in a decrease in land productivity (Case in Suntenjaya Village). This can be seen from the decrease in C-organic content and total $\mathrm{N}$-nutrient content, $\mathrm{P}_{2} \mathrm{O}_{5}, \mathrm{~K}$, and Ca (Table 2).

Table 2.Soil Nutrient Content in Suntenjaya Village, Lembang District (2004 and 2008)

\begin{tabular}{|c|c|c|c|c|}
\hline \multirow{2}{*}{ Type of Analysis } & \multirow{2}{*}{ Unit } & \multicolumn{2}{|c|}{ Results of Analysis } & \multirow{2}{*}{$\begin{array}{c}(\%) \\
\text { Penurunan }\end{array}$} \\
\hline & & Year 2004* & Year 2008** & \\
\hline C-organik & $\%$ & 4,23 & 1,69 & 60,05 \\
\hline N-total & $\%$ & 0,38 & 0,21 & 44,74 \\
\hline $\mathrm{P}_{2} \mathrm{O}_{5}$ (Bray 1 ) & ppm & 26,54 & 12,66 & 52,30 \\
\hline $\mathrm{K}$ & $\mathrm{me} / 100 \mathrm{~g}$ & 0,77 & 0,58 & 24,68 \\
\hline $\mathrm{Ca}$ & $\mathrm{me} / 100 \mathrm{~g}$ & 5,58 & 4,06 & 27,24 \\
\hline
\end{tabular}

Description: $*=$ Sutrisna and Surdianto (2007)

$* *$ = Primary data (results of soil analysis)

Erosion that erodes the topsoil is bad for the soil and plants. The results of Cuff's (1978) study in Mastur et al. (2000), shows that erosion eroding $1 \mathrm{~cm}$ of the soil layer in an area of 1 ha will carry the equivalent of $350 \mathrm{~kg}$ of nitrogen $(\mathrm{N}), 90 \mathrm{~kg}$ of phosphate $(\mathrm{P}), 1,000 \mathrm{~kg}$ of potassium $(\mathrm{K}), 650 \mathrm{~kg}$ of magnesium $(\mathrm{Mg})$, and $1,050 \mathrm{~kg}$ of calcium $(\mathrm{Ca})$. Table 2 also shows that the decrease in soil $\mathrm{C}$-organic content is the highest compared to other nutrients. This is presumably because $\mathrm{BO}$ lost due to erosion is not comparable with BO given in each growing season. In the long run the decrease in content will be greater, along with other nutrients (phosphorus and potassium) and will have an impact on plant productivity. Subardja (2006) states that changes in land use can reduce corn productivity due to a decrease in soil quality. Soil quality that is very influential on the productivity of maize crops is nutrient availability, nutrient retention, and the suspected hazard of aluminum poisoning from land characteristics, namely $\mathrm{P}$ is available, $\mathrm{pH}$ and $\mathrm{Al}$ are interchangeable. According to Nugroho et al. (2002), changes in land use have the greatest influence on changes in the hydrological conditions of a watershed. Changes in land use from agricultural land to settlements, in addition to causing changes in peak discharge also lead to an increase in direct flow (direct run-off) from $53 \%$ to $60 \%$. This is due to the change in land use which causes an increase in the percentage of water-resistant areas, thus contributing directly to the increase in direct run-off.

If land damage occurring in upstream areas of subwatershed Cikapundung continues to be left, so that there are no control measures, it is possible for the land to become critical. In some locations critical land 
has been found as shown in Figure 1. Land becomes unproductive because it cannot be used again for agricultural businesses, even if it will be sought, it requires very high costs.

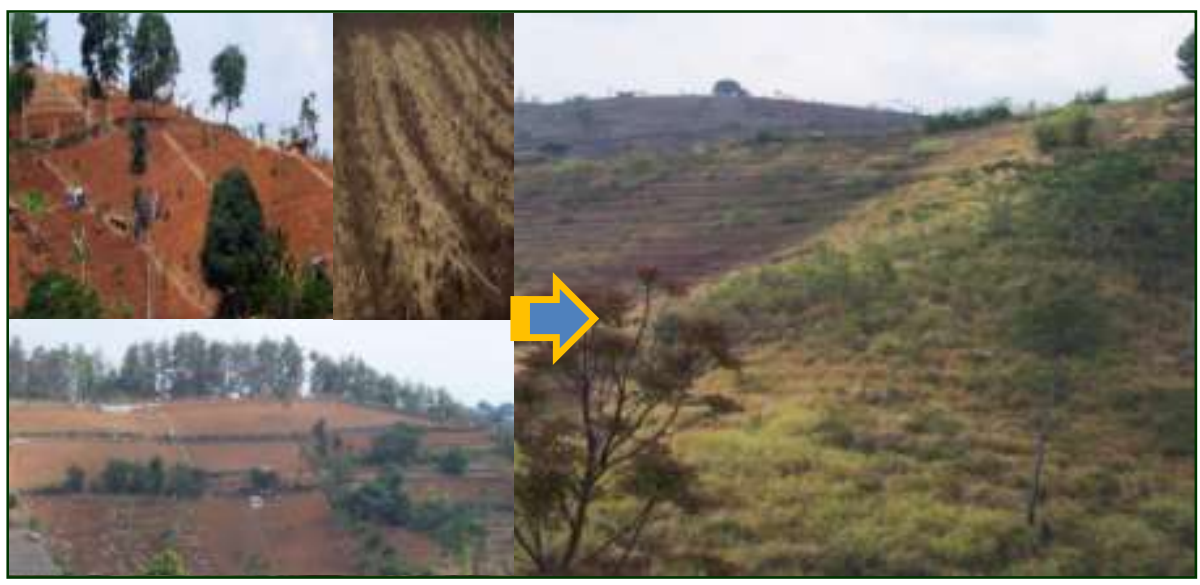

Figure 1. Land Condition in the Upper Cikapundung Sub-watershed which is Wrong in Management Causing Land to Be Critical.

\section{Implementation of Conservation Farming Systems for Vegetable Plants in Upstream Areas of Subwatershed Cikapundung}

The intensive cultivation of vegetable crops in upstream areas of subwatershed Cikapundung, farmers must implement a conservation farming system so as not to damage the environment and the land can be utilized sustainably. The implementation of a conservation farming system, farmers must pay attention to several things, including: land management systems, planting systems, and the selection of the most suitable plants (Abas et al., 2004). Appropriate and appropriate tillage and planting systems are essential to minimize the level of erosion that occurs. According to Suganda et al. (1999), vegetable planting systems affect the ability of canopy closure to withstand rain grains, thereby reducing erosion rates.

Field observations and interviews with respondents showed that around $63.6 \%$ of farmers implemented a shifting intercropping system (planting more than one type of plant in a different stretch of land with different planting times) and intercropping (planting more than one type of plant in one stretch of land with the same planting time).

\section{Farming System for Vegetable Plant Conservation in Upstream Areas of Subwatershed Cikapundung}

The results of the Sutrisna et al., 2010 study show that there are two systems for farming vegetable conservation that can be applied in the Upper Cikapundung watershed, namely: (1) Farming system for conservation of ridge terraces, beds cutting slopes, using manure + lime, installed plastic mulch, a system of planting intercropping of vegetables with multiple overlays. This conservation farming system is suitable to be applied to land that has a slope of $8-15 \%$ and (2) Conservation farming system of bench terraces, beds cutting slopes, using manure + lime, plastic mulch installed, system of planting intercropping / overlapping vegetables. This conservation farming system is suitable to be applied to land with a slope of $15-25 \%$. The types of plants applied in the conservation farming system are divided into 3 groups, namely: (1) Group 1: Beans and Cucumbers, (2) Group II: Cayenne Pepper, Red Chili, Tomatoes, and Potatoes, and (3) Group III: Col flowers, salada, mustard greens, and cabbage. Grouping of plants is based on height, canopy area, and type of growth, namely shrubs, creeping and fringing. Each type has different abilities in intercepting rainwater granules. The application of the vegetable conservation farming system on the slope of $8-15 \%$ can 
be seen in Figure 2, while the application of the vegetable conservation farming system on the slope of 15$25 \%$ can be seen in Figure 3.

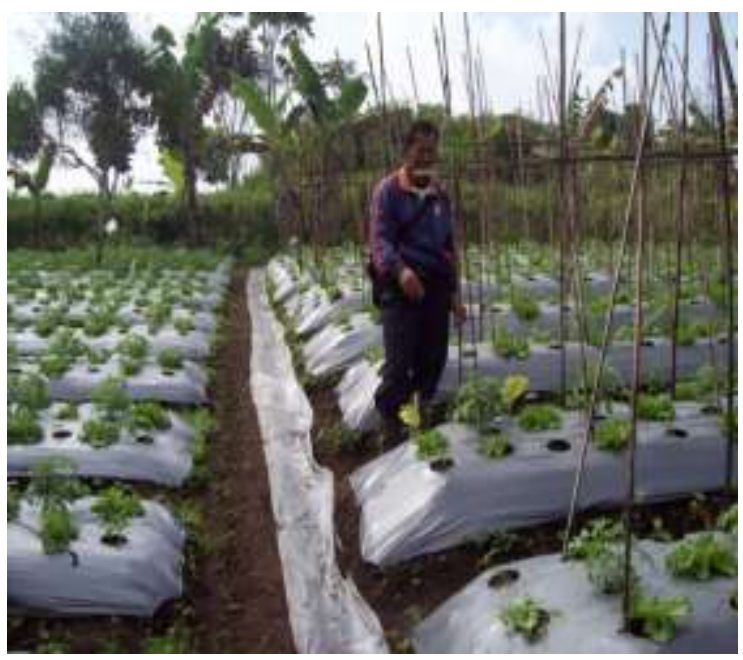

Description::

Slope : $10 \%$

Plant type

Season 1

Season 2

Cropyng

System

Figure 2. Conservation Farming System Type A

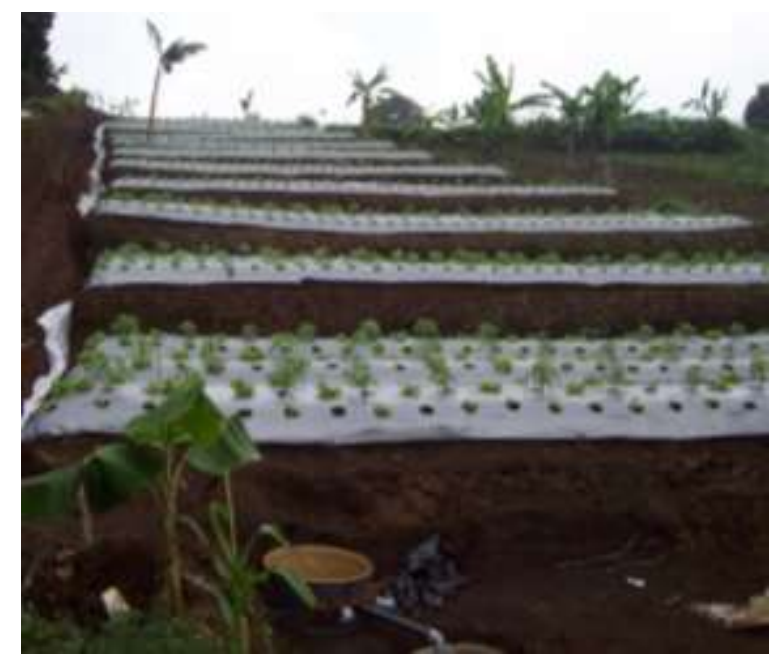

Description::

Slope : $22 \%$

Plant type

Season 1

Group 2: Cayenne paper + Tomato

Group 3: Salada

Season 2

Group 3: Broccoli

Cropyng : Intercropping and rolling

System season

Figure 3. Conservation Farming System Type B

Intercropping and overlapping cropping systems, namely: (1) Intercropping: in one field (guludan), planted with several types of vegetable plants and (2) Rolling season: after one type of crop is harvested the following season is planted with other types of plants. In this study, Salada plants were harvested after 2 months, then mixed with Broccoli.

\section{Technical Feasibility}

One of the technical feasibility indicators used is the amount of erosion that occurs through predictions of erosion using the RUSLE method. According to Sinukaban et al., (1994), a conservation farming action or model can be said to be feasible so that it can be recommended if the amount of erosion that occurs is smaller than tolerable soil loss (TSL). The erosion prediction results showed that the application of type A conservation farming systems on the 10\% slope was able to control erosion from 69.93 to $7.18 \mathrm{t} / \mathrm{ha} /$ year (conservation farming systems commonly applied by farmers) or equal to $89.73 \%$. Meanwhile, the application of the Type B conservation farming system was able to reduce erosion from 37.41 to $15.27 \mathrm{t} / \mathrm{ha}$ /year (the conservation farming system commonly applied by farmers) or by $59.18 \%$.

According to Arsyad (2006), the value of T in deep soil with its lower layer is permeable, above the substrate which has decayed as in the upstream sub-watershed of Cikapundung is 2.5. The weight of soil contents in the upper Cikapundung sub-watershed in Suntenjaya Village was $0.68 \mathrm{~g} \mathrm{~cm}-3$, so the amount of erosion that is still allowed is $17.00 \mathrm{t} / \mathrm{ha} / \mathrm{yr}$. The calculation results using the Hammer method (1981) are also the same, the TSL value of land in the upper Cikapundung sub-watershed is $16.89 \mathrm{t} / \mathrm{ha} / \mathrm{year}$, rounded to 17 , $00 \mathrm{t} / \mathrm{ha} /$ year. Thus, the Type A and Type vegetable farming systems are technically feasible recommended in the upstream Cikapundung watershed. 
This is in line with the results of the study by Syam (2003) showing that the farming system of bench terrace and terracing farming in accordance with the local agroecosystem zone can reduce erosion rates and increase farm productivity and farmer income. According to Hawkins et al. (1991), conservation farming that combines civil (technical) and biological (vegetative) conservation measures with spatial arrangements for annual crops, annual plants, legume plants for conservation as well as producers of organic fertilizers and forages, as well as grass; taking into account the face shape and landscape characteristics are very suitable to be developed on sloping land, such as in upstream areas of subwatershed Cikapundung.

\section{Financial Feasibility}

According to Kadariah et al,. (1999), whether or not an activity or project is feasible; in this case conservation farming can be seen from the results of financial analysis. Indicators of eligibility can be seen from: (1) Benefit Cost (BC) Ratio; said to be feasible if $\mathrm{BC}$ Ratio $\geq 1$ and said to be inappropriate if BC Ratio $<1$, (2) Net Present Value (NPV); said to be feasible if NPV $\geq 0$ and said to be inappropriate if NPV $<0$, and (3) Internal Rate of Return (IRR); said to be feasible if the IRR $\geq$ Social Discount Rate and is said to be inappropriate if the IRR < Social Discount Rate.

Vegetable commodities analyzed in the farming system for conservation of vegetable crops in the upper Cikapundung watershed are salada, cayenne pepper, tomatoes, and broccoli. The planting system is a summoner, meaning that the crop is available throughout the year, so the analysis is carried out every year not every season as in other seasonal crop commodities. The total cost used is all investment and operational costs, namely production facilities and labor. The production facilities used are manure, lime, seeds/seeds, inorganic fertilizers, and pesticides in accordance with the recommendations. The use of labor is all labor costs incurred for farming activities (including landowners who work on their own land).

The financial feasibility analysis of the farming system for vegetable crop conservation in the upper Cikapundung sub-watershed uses several assumptions, namely: (1) for 6 years conservation buildings do not require high maintenance costs, (2) the use of manure and lime fertilizer can last for 3 years, and (3) the results of the results used are the results of research on the conditions of land, commodities and cultivation technology that are the same as the chosen conservation farming model. The financial feasibility of farming systems for conservation of vegetable crops in upstream areas of subwatershed Cikapundung is presented in Table 3. Table 3 shows that the farming systems for conservation of Type A and B vegetable crops are financially feasible to be recommended in the upper Cikapundung watershed. This is indicated by the value of BC Ratio> 1, NVP> 0, and IRR>The current Social Discount Rate or Bank interest, which is around $12 \%$.

Table 3. Financial Feasibility of Application of Type A and Type B Vegetable Conservation Farming Systems at 12\% Interest Rate

\begin{tabular}{|c|c|c|c|c|}
\hline No. & Description & Existing Type & Type A & Type B \\
\hline \multirow[t]{3}{*}{1} & BC Ratio & & & \\
\hline & - $\quad$ Yasr to-2 & & 1,28 & 0,90 \\
\hline & - $\quad$ Year to-6 & & 1,40 & 1,12 \\
\hline \multirow[t]{4}{*}{2} & Income/NPV & & & \\
\hline & - $\quad$ Year to-1 & 12.430 .000 & 21.153 .000 & 20.165 .000 \\
\hline & - $\quad$ Year to-3 & & 25.043 .500 & 20.815 .100 \\
\hline & - Year to-6 & & 22.682 .500 & 20.737 .900 \\
\hline 3 & IRR & & $21,96 \%$ & 17,76 \\
\hline
\end{tabular}




\section{Conclusion}

The farming system for conservation of Type A and B vegetable crops is technically and financially feasible recommended in upstream areas of subwatershed Cikapundung. The conservation system for Type A vegetable crops is recommended on land with a slope of $10-15 \%$ while Type B on land with a slope of 15$25 \%$. In order for the system to be sustainable it needs to be supported by institutional subsystems to improve synergistic relations between related institutional elements, especially in the provision of production facilities. The farming system for conserving vegetables in the upper reaches of the Cikapundung subwatershed requires a large amount of manure production facilities. This can be done by integrating the vegetable farming system with dairy cattle.

\section{References}

Abas, A., Y. Soelaeman, dan A. Abdurachman. 2004. Keragaan Dampak Penerapan Sistem Usahatani Konservasi terhadap Tingkat Produktivitas Lahan Perbukitan Yogyakarta. J. Litbang Pertanian. 22:49-56.

Arsyad, S. 2006. Konservasi Tanah dan Air. Edisi ke-2. Bogor. IPB Press.

Darsiharjo. 2004. Model Pemanfaatan Lahan Berkelanjutan di Hulu Sungai (Studi Kasus daerah hulu sungai Cikapundung Bandung Utara). Disertasi Sekolah Pascasarjana. Institut Pertanian Bogor. Bogor.

Hawkins, R., H. Sembiring, D. Lubis, and Suwardjo. 1991. The Potential of Alley Cropping in the Uplands of East and Central Java. Upland and Agriculture Conservation Project-Farming System Research, Agency for Agriculture Research and Development. Salatiga.

Hermon, D. 2001. Studi Kontribusi Penggunaan Lahan dan Vegetasi Terhadap Karakteristik Epipedon. Tesis Magister. Program Pascasarjana Universitas Andalas Padang.

Hermon, D. 2009. Dinamika Permukiman dan Arahan Kebijakan Pengembangan Permukiman pada Kawasan Rawan Longsor di Kota Padang. Disertasi. IPB Bogor.

Hermon, D. 2010. Geografi Lingkungan: Perubahan Lingkungan Global. UNP Press.

Hermon, D. 2011. Studi Karakteristik Epipedon berdasarkan Penggunaan Lahan di Kecamatan X Koto Kabupaten Tanah Datar. Universitas Andalas.

Hermon, D. 2012. Mitigasi Bencana Hidrometeorlogi: Banjir, Longsor, Degradasi Lahan, Ekologi, Kekeringan, dan Puting Beliung. UNP Press. Padang.

Hermon, D. 2014. Impacts of Land Cover Change on Climate Trend in Padang Indonesia. Indonesian Journal of Geography. Volume 46. Issue 2. p: 138-142. Fakultas Geografi Universitas Gajah Mada.

Hermon, D. 2015. Geografi Bencana Alam. Jakarta: PT RajaGrafindo Persada.

Hermon, D. 2016. Mitigasi Perubahan Iklim. Rajawali Pers (Radjagrafindo).

Kadariah., L. Karlina, dan C. Gray. 1999. Pengantar Evaluasi Proyek. Lembaga Penerbit Fakultas Ekonomi Universitas Indonesia. Jakarta.

Mastur; S.M., H. Narioka, Anase, and Yasutomi. 2000. Soil Characteristics. Farming system and conservation strategies in the sloping volcanic areas in Indonesia. J.Jpn. Soc. Soil Phys. 85:19-29.

Nugroho, S.P. 1999. Sistem Pendekatan Konservasi Tanah dan Air untuk Optimalisasi Pemanfaatan Lahan Kritis. J. Air, Lahan, Lingkungan, dan Mitigasi Bencana. 4:1-7.

Oktorie, O. 2017. A Study of Landslide Areas Mitigation and Adaptation in Palupuah Subdistrict, Agam Regency, West Sumatra Province, Indonesia. Sumatra Journal of Disaster, Geography and Geography Education. Volume 1. Issue. 1. p: 43-49. Master Program of Geography Education.

Simonato, Tommaso, G.B. Bischetti, and G.B. Crosta,. 2002. Evaluating Soil Erosion with RUSLE and WEPP in an Alpine Environment (Dorena Valley - Central Alps, Italy), inSustainable Land Management - Environmental Protection A Soil Physical Approach, Chapter V, Pagliai, M., Jones, R., Editor, IUSS, 481-494. 
Sinukaban, N., H. Pawitan, S. Arsyad, J.L. Amstrong, and M.G. Nethary. 1994. Effect of Soil Conservation Practice and Slope Lengths on Run off, Soil Loss, and Yield of Vegetables in West Java. Australian J. of Soil and Water Conservation. 7:25-29.

Sitorus, S.R.P. 2007. Kualitas, Degradasi, dan Rehabilitasi Lahan. Sekolah Pascasarjana. IPB. Bogor.

Subardja, H.D. 2006.Pengaruh Kualitas Lahan terhadap Produktivitas Jagung pada Tanah Volkanik dan Batuan Sedimen di Daerah Bogor.J. Tanah dan Iklim. 6:21-29.

Suganda, H., M.S. Djunaedi, M.S. Santoso, dan S. Sukmana. 1999. Pengaruh Arah Barisan Tanaman dan Bedengan dalam Pengendalian Erosi pada Budidaya Sayuran Dataran Tinggi. J. Tanah dan Iklim. 17:55-64.

Suroso dan H.A. Susanto. 2006. Pengaruh perubahan tata guna lahan terhadap debit banjir daerah aliran sungai Banjaran.J. Teknik Sipil. 3:75-80.

Sutrisna, N. dan Y. Surdianto. 2007. Pengaruh Bahan Organik dan Interval serta Volume Pemberian Air terhadap Pertumbuhan dan Hasil Kentang di Lahan Dataran Tinggi Lembang. J. Hort 17:224-236.

Sutrisna, N., Santun RP Sitorus, dan K. Subagyono. Tingkat Kerusakan Tanah di Hulu Sub DAS Cikapundung Kawasan Bandung Utara J. Tanah dan Iklim.32:71-82.

Sutrisna, N., Santun RP. Sitorus, B. Pramudya, dan Harianto. Alternatif Model Usahatani Konservasi Tanaman Sayuran di Hulu Sub-DAS Cikapundung.J. Hort. 20(3):223-240

Syafruddin., A.N. Kairupan, A. Negara, dan J. Limbongan. 2004. Penataan Sistem Pertanian dan Penetapan Komoditas Unggulan pada Zone Agroekologi di Sulawesi Tengah. J. Litbang Pertanian. 23:61-67.

Syahyuti. 2006. Konsep Penting dalam Pembangunan Pedesaan dan Pertanian. Jakarta. PT. Bina Rena Pariwara. $262 \mathrm{hlm}$

Syam, A. 2003. Sistem Pengelolaan Lahan Kering di Daerah Aliran Sungai Bagian Hulu. J. Litbang Pertania., 22:162-171.

Wicaksono, A.H. 2003. Penggunaan Lahan dan Pengaruhnya terhadap Kualitas Tanah. J. Penelitian UNIB. IX:85-88. 